\title{
EMPLOYERS' ASSESSMENT OF MANAGEMENT SCIENCE GRADUATES FROM NIGERIAN UNIVERSITIES
}

\author{
Edith Onowe Odia ${ }^{1}$, Benedicta Okaima Imasuen ${ }^{2}$ \\ ${ }^{1}$ Department of Marketing, Faculty of Management Sciences, University of Benin, Benin \\ City, Nigeria \\ ${ }^{2}$ Department of Educational Studies and Management, Faculty of Education, University of \\ Benin, Benin City, Nigeria \\ edyy2002ng@yahoo.com \\ eliotaimd@hotmail.com
}

\begin{abstract}
In view of deteriorating quality of graduates from Nigerian tertiary institutions, this study sought to determine employers' assessment of management science graduates on key employability skills. The study involves the administration of questionnaires by means of convenience sampling on 680 employers of management science graduates in public and private sectors in Edo/Delta States. T-test and ANOVA were used to analyse data. Notwithstanding the age difference, the result obtained shows that employers rated the graduates of management sciences as slightly 'fair'. Notably, employers in the private sector rated management graduates higher and more positively than their counterparts in the public sector. Additionally, the employers in the present study described management science graduates as reliable, employable and hardworking. It was recommended that the quality of management science graduates can be improved by placing emphasis on increased funding, infrastructural development, and educator-employer based curriculum which focuses on practical skills, as well as the reactivation of industrial attachment in the Nigerian universities. On the side of the employers, investment in the orientation and training of new entrants into work organization should not be neglected.
\end{abstract}

Keywords: Employers' assessment, Management science graduates, Public/Private universities, Nigerian universities, University generations.

JEL classification: 1210 .

\section{Introduction}

Education as one of the fundamental human right has been noted as the source and bedrock of any nation's economic, political, social and technological development. Judging from the Japanese experience, Adefuye (1999) argued that labour is the pivot and catalyst for national development. In the words of Ofulue and Nwakwushue (2008:166), "no nation would make any meaningful socio-economic stride without viable educational institutions." In corroboration, Odunaike, ljaduola and Epetimehin (2012) acknowledged that a nation's education system forms the bedrock of its economic, political and technological development and a major determinant of its GDP.

The perennial and deteriorating quality of education in Nigeria impacts negatively on the welfare of individual citizens and the nation at large (Adewuya, 2002; Alumode, 2006; Ezenwafor, 2006). Today, a number of challenges face our tertiary institutions especially that of quality control, both in content and environment. It has been observed that Nigerian educational system has continued to witness huge and colossal quantitative growth at the expense of its qualitative development. Painfully, Akpa (2006) noted that over 60\% graduates from tertiary institutions are classified as unskilled and untrained. In 
corroboration, Obanya (2002), Pitan and Adedeji (2012), Pitan (2016); and Rufai, Bakar and Rashid (2015) observed that Nigerian graduates have variously been described as half-baked, ill -equipped, ill-trained, of poor quality, of poor standard and unemployable.

Ibrahim and Dandago (2013) observed that at the national and global economic levels, employers are now focusing on the demand of graduates with high soft (ICT) skills, technical skills and competencies than academic excellence. This changing pattern in the labour market increases the complexity of skills needed by graduates to secure gainful employment (lbrahim and Dandago, 2013). In addition, Aluko (2014:549) noted that "employers want workers who are already made to perform, because markets are becoming more competitive and cost of on-the-job training is becoming prohibitive. In Nigeria, an overall skill mismatch of 60.6 percent among employed university graduates has been recorded (Pitan and Adedeji, 2012). In a related manner, Rufai et al. (2015) remarked that the training received by graduates from higher education institution has little or no relevance to the social and economic needs of their countries.

According to the National Bureau of Statistics (NBS), the unemployment rate in Nigeria in 2010 was $21 \%$, it increased to $23.9 \%$ in 2011 and 54\% in 2012 (Abiola, 2014). Emeh, Nwanguma and Abaroh (2012) and Pitan (2015) observed that the high rate of unemployment experienced by university graduates in Nigeria, is not necessarily due to unavailability of jobs, but partially cause by a dearth of candidates with employable skills demanded by employers. In a related manner, Akanmu (2011) noted that many employers of graduates are raising serious concerns about their skills and fit for the job.

\section{Significance of the Study}

The higher the level of mismatch between graduate turnout and graduate employable skills, the greater the level of crime, unfulfilled dreams, suicide, and impaired financial positions (Akinyemi, Ofem, and Ikuenomore, 2012). This unpleasant condition emanating from the nation's education/labour market disconnect is unhealthy for graduates, educators and national human capita development in general and particularly for management science graduates. This is critically so because the survival of any organization, small or large scale, is dependent on the managerial skills possess by their managers. The question of interest is the employers' perception of management science graduates different from the negative assessment of the other graduates. Against this background, the need to determine employers' assessment of graduates of management sciences from Nigerian universities is timely and cannot be overemphasized as Nigeria's formal education system has been keenly noted to be contributing to high unemployment rate, crime and poverty (Akhuemokhan, Raimu and Sodoluwe, 2013).

\section{Objective of the Study}

The following are the objectives of this study.

1. To determine employers' perception of Nigerian management science graduates from Nigerian universities.

2. To investigate if employers' demographics influence their image of the Nigerian management graduates.

3. To ascertain if significant variation exist in the employers' perceptions of management graduates from public and private universities

4. To ascertain if significant variation exist in the employers' perceptions of management science graduates from the different generational universities

5. To determine if employers' assessment of the female management graduates differ from those of their male counterparts. 


\section{Literature Review}

\subsection{Determinants of Graduate Employability}

Irrespective of organization's size or type, Branine (2008) discovered that employers are employing cost-effective recruitment strategies that focus more on personal attributes like the attitudes, personality and transferable skills than job-centred skills relating to the type or level of applicant qualification. Hodges and Burchell's (2003) assessment of business graduates' workplace preparedness revealed that soft skills are very important. In line with Hodges and Burchell (2003), the study of McCabe (2010) acknowledged that hard skills such as knowledge and personal attributes are no longer sufficient to guarantee job retention except graduates possess soft skills. In an investigation on skills and competences required by applicants to secure gainful employment, Graham (2001) found besides verbal expression, presentation skills, listening, and understanding instructions, that employers also give critical attention to teamwork spirit, leadership skills, dedication, and initiative skills. In the exploration of UK, Austrian, Slovenian and Romanian business graduate employability, Andrews and Higson (2008) classifies the core components of employment to include work-experience, hard business-related knowledge and skills and soft business-related skills and competencies. Regarding graduate employability, Saunders and Zuzel (2010) noted that employers ranked personal qualities and core skills more highly than technical and subject-specific skills. In line with other pioneering works, Blom and Saeki (2011) identify soft skills and communication skills as core employability skills. Singh and Singh (2008) also observed that employers rated graduates with information communication technology (ICT) and communication skills more favorably than other groups.

The study of Ting and Ying (2012) showed no significant difference between the practitioners and academicians on business graduates' competencies on resourcefulness, research skills, written skills, oral skills, knowledge-acquiring skills, honesty, diligence, value-improving, teamwork ability, innovative skills and computer skills. However, Imeokparia and Kennedy (2012) observe that business graduates thinking skills are not as high as personal quality skill. They concluded that the current level of skills possessed by business graduates is satisfactory to secure placement in the workplace.

In the opinion of MdSaad, Robani, Jano and Ab. Majid (2013), problem-solving, tool handling competency and presentation skills are employable skills highly sought by employers. Balaceanu, Zaharia, Tilea, Predonu, Apostol and Dogaru (2013) in the evaluation of employers' satisfaction with graduate employee skills concluded that their employees' knowledge is adequate and consistent with their requirements. However, they noted that their main area of weakness was lack of practical experience. They thereafter recommend that school curricula be adjusted to accommodate more practical training especially with business practitioners.

Hettige (2000) on students' counseling and welfare services, in Sri Lanka, identified determinants of graduates employability to be team spirit, ability to achieve results in a short period and to prioritize/organise time productivity, openness, positive thinking, practical mind set, wide interest, personal character and business ethics. Ariyawansa (2008) found that English language proficiency is a key factor in graduate employability in addition to competence in IT skills, leadership qualities, analytical ability, team work, interpersonal relations and a degree certificate. In conclusion, Ariyawansa (2008) recommends that basic IT skills and English proficiency should be entry requirements for applicants seeking university admission.

Obanya (2002) suggests that university education should develop in the beneficiary analytical power relating logical reasoning, verbal skills, quantitative, graphic, documentary, audio- virtual, and sensory- perceptions skills; oral and written communication; 
problem-solving; team spirit; creativity; versatility; IT (Information Technology) ; life-long learning skills such as perseverance, risk-taking, a spirit of enquiry, reading as a habit, self-directed learning efforts, the ability to face challenges. The study of Adeyemo, Ogunleye, Oke and Adenle (2010) examined the quality of university graduates on the following parameters: oral communication skill, subject specific knowledge skills, basic skills of reading and writing, entrepreneurship skills, technical/technological skills, problem solving/decision making skills, IT skills, self-directed learning skills and analytical/critical thinking skills.

\subsection{University Ownership/Management and Graduate Employability}

On the relationship between education and employment opportunities among 93 employers in a state, semi-state and private sectors in Sri Lanka, Gunawardena (1997) findings showed that the largest number of response (34\%) opined that communication skills is a major criterion for selecting graduates for employment. Among other criteria highlighted are external appearance, manners, ethics, personality, respect to others, ability to work as a team, interpersonal skills and leadership. In the same study, a significant difference was found between the employers in government sector $(66.7 \%)$ and private sector $(89.6 \%)$ on the importance of English proficiency.

Singh and Singh (2008) in a study found that graduates from public universities were preferred for employment than those from private universities. They also found that younger employers rated graduate employability skills better than their counterparts. In a comparative study of public and private sector employers' perception on quality and employability of university graduates', Anho (2011) found a significant difference between the two sectors. In conclusion, he noticed that employers in private sector rated the quality of university graduates higher than their public sector counterparts. For the private sector employments, Cole (1993) identifies manual/social/intellectual skills, knowledge, understanding and attitudes as some of the requirements. Additionally, English proficiency, and IT skills, etc. have been noted as critical determinants of graduates' employability in Sri Lankan organizations (Ariyawansa and Perera, 2005).

A survey of newspaper advertisements on job opportunities and telephone conversations with managers from government, non-governmental and private organizations by Ariyawansa (2008) showed that prior work experience is highly demanded by employers in private sector. A significant difference was found between public and private universities on the quality of management education curriculum. Students in private universities rated their academic programme on technical skills, report writing skills, interpersonal skills, and computer skills higher than their counterparts from public universities (Odia and Agbonifoh, 2014). In Ambepitiya's (2016) study, graduates from public university indicated that they were satisfied with the knowledge acquired, more of those from private were dissatisfied Many graduates from both institutes, however, agreed that the acquired knowledge had supported them in their employment

Following the review of the literature, the present study propose to evaluate employers' assessment of management science graduates on writing skills, that is report writing, oral communication skills, report presentation skills leadership skills, decision making skills problem solving skills, interpersonal skills, trainability, and computer knowledge/lT skills.

\section{Methods}

\section{Research Design}

A combination of the descriptive and correlational research design was employed in the present study. Correlation research enables the direction and magnitude of relationship between variables to be established (Fraenkel and Wallen, 2000). 


\section{Sample Selection and Technique}

A non-probability convenience sampling was used to distribute questionnaires to the respondents. According to Starmass (2007), the benefits of convenience sampling are low cost and time saving; which is most comfortable for study with homogeneous population. The study involved both the public and private employers of labour in Edo/Delta States, Nigeria. For deeper coverage, top managers in large scale organizations who had management science graduates under their supervision were also include in the sample. A sample of 680 respondents was considered to be representative for the present study since Management science graduates in (Accounting, Business Administration, Banking/Finance, Actuarial Science, Insurance, Marketing, Global Management, Human Resource Management etc) from all Nigerian universities of different generations were assessed by their employers. The Nigerian federal universities have been categorized into groups based on their dates of establishment, as follows: 1st Generation (Benin, Ibadan, Ile-Ife, Lagos, Nsukka, Zaria); 2nd Generation (Calabar, Ilorin, Jos, Kano, Maidugari, Port Harcourt, Sokoto); $3^{\text {rd }}$ Generation (Abeokuta, Abuja, Akure, Akwa, Bauchi, Makurdi, Minna, Owerri, Umudike, Uyo, Yola) (Adeyemo, et al., 2010). A total of 650 questionnaires were retrieved, 628 were only usable. Of the 628 usable questionnaires from respondents, 446 were male and 182 were female. While 263 were employers in the public sector and 348 in the private sector.

\section{Method of Data Collection}

As an empirical study, primary and secondary sources were employed for data collection. A self-designed questionnaire was used for collection of primary data, while secondary data were sourced from extant literature contained in journal, theses, conference proceedings, and working papers that were relevant to the subject of investigation. Self-administered questionnaires was adopted in this study because, it ensures respondents privacy, which may encourage them to objectively disclose their true feelings and perceptions (Cooper and Schindler, 2011). Additionally, this instrument of data collection is acknowledged to be cost-effective (Struwig and Stead, 2001). The research instrument was designed to capture respondent's demographics including age, sex, educational level and organization type. Section B of the survey questionnaire consisted closed-ended questions and focused on measuring employers' perception of management science graduates from different generational universities. Examples of issues raised in this section bothered on items evaluating graduates' writing skills, that is report writing, oral communication skills, report presentation skills leadership skills, decision making skills problem solving skills, interpersonal skills, trainability, and computer knowledge/ICT skills. These management graduate performance parameters were measured on a five-point Likert scale.

\section{Pilot testing for Validity and Reliability of Research Instrument}

A pilot study was conducted to check for vagueness and ambiguities in the questionnaire. To ensure validity of the instrument, the questionnaire was given to four experts in the Departments of Business Administration and Education, University of Benin, Benin City to validate the instrument. Based on the suggestions of the experts, adjustments were made to improve the final questionnaire. Thereafter, the questionnaire was then piloted to test for reliability. The questionnaire was pre-tested among 20 employers of management graduates. The reliability coefficient of the survey instrument was computed using Cronbach's alpha test. The reliability coefficient for the 16 items exceeded the cut-off $\alpha$ of 0.70 (Girden, 2001). Hence, the measurement instrument was certified as reliable and internal consistent with a coefficient value of 0.840 . 


\section{Fieldwork/Questionnaire Administration}

Given the size of the research area, involving two states, Edo and Delta, data were collected from the respondents directly with the assistance of eight research assistants. In order to ensure representativeness of the samples, the questionnaires were administered to employers and managers in small, medium and large scale organizations who had management science graduates under their employment or supervision.

\section{Data Analysis Method}

Both descriptive and inferential statistics including mean, Z-test and ANOVA-test were used in analyzing data.

\section{Results}

Table 1: Employers' Assessment of Management Science Graduates from Nigerian Universities

\begin{tabular}{|l|l|l|l|}
\hline $\mathbf{S} / \mathbf{N}$ & $\begin{array}{l}\text { Parameters for Assessing Nigerian Management Science } \\
\text { Graduates }\end{array}$ & Mean & $\begin{array}{l}\text { Std } \\
\text { Dev }\end{array}$ \\
\hline 1 & Knowledge of the professed area of specialization & 3.80 & .776 \\
\hline 2 & Writing skills, that is report writing and minutes of meeting & 3.72 & 1.464 \\
\hline 3 & Oral communication skills & 3.75 & .730 \\
\hline 4 & Report presentation skills & 3.60 & .816 \\
\hline 5 & Leadership skills & 3.68 & .826 \\
\hline 6 & Ability to work with little or no supervision & 3.66 & .878 \\
\hline 7 & Decision making skills & 3.62 & .820 \\
\hline 8 & Problem solving skills & 3.60 & .841 \\
\hline 9 & Interpersonal skills (relationship with others) & 3.80 & .789 \\
\hline 10 & Observance of ethical standards & 3.55 & .865 \\
\hline 11 & Trainability (whether employee is trainable) & 3.80 & .827 \\
\hline 12 & Familiarity with current developments in area studied and the job & 3.77 & 2.170 \\
\hline 13 & Computer knowledge/IT skills & 3.59 & .881 \\
\hline 14 & $\begin{array}{l}\text { How would you rate Nigerian educational system when you compare } \\
\text { this employee with his/her counterparts from foreign universities }\end{array}$ & 3.38 & .846 \\
\hline 15 & Overall quality of employee's outputs & 3.54 & .716 \\
\hline 16 & $\begin{array}{l}\text { If you were to make future important recruitment, to what extent would } \\
\text { you consider Nigerian graduates in management studies before their } \\
\text { foreign universities }\end{array}$ & 3.48 & .985 \\
\hline & Overall Average & 3.65 & .124 \\
\hline
\end{tabular}

Source: Authors' Fieldwork

The mean value of 3.65 indicates that employers' overall assessment of management graduates from Nigerian universities is fairly above average. The management graduates were rated equal with the highest mean index of 3.80 on three dimensions: knowledge of professed area of specialization, interpersonal skills and trainability. In comparison with their foreign counterparts, management science graduates from Nigerian universities were rated poorly as they were perceived to be of lower standard. 
Oradea Journal of Business and Economics, Volume III, Issue 2

Published on September 2018

Table 2: Employers' Rating of Management Graduates Performance on the Basis of Sex

\begin{tabular}{|l|l|c|c|c|c|}
\hline Parameter & Employers' Sex & $\mathbf{N}$ & Mean & Std. Deviation & $\begin{array}{c}\text { Std. Error } \\
\text { Mean }\end{array}$ \\
\hline \begin{tabular}{l} 
Rating $\begin{array}{l}\text { Management } \\
\text { Graduates }\end{array}$ \\
\cline { 2 - 6 }
\end{tabular} & Female & 446 & 3.64 & .623 & .029 \\
\cline { 2 - 6 } & Male & 182 & 3.62 & .581 & .043 \\
\hline
\end{tabular}

Levene $\mathrm{F}=1.050 \mathrm{P}=.306 \mathrm{t}=.481 \mathrm{P}=.630$

Source: Authors' Fieldwork

Given the t value of .481 and $p$-value of .0630 , it could be seen that employers' sex was not relevant in their evaluation of management graduates' performance. In other words, both the male and female employers rated performance of management graduates as fairly positive.

Table 3: Age and Education Influences on Employers' Rating of Management Science Graduates

\begin{tabular}{|l|c|c|c|}
\hline Demographic Variables & B Coefficients & t & Sig. \\
\hline (Constant) & 3.575 & & \\
\hline Employers' Age & .001 & 28.695 & .000 \\
\hline Employers' Education & .018 & .293 & .770 \\
\hline
\end{tabular}

R Squared $=.001 ; \mathrm{F}=.157 ; \mathrm{P}=.854$

Source: Authors' Fieldwork

The multiple regression results relating to age and educational influences on employers' rating of management graduates revealed that only employers' age factor had significant impact at $\mathrm{t}(28.695)$ and $\mathrm{p}(0.00)$. On the other hand, the F-value of 0.157 and $\mathrm{p}(0.854)$ indicate an insignificant joint impact of the two variables with $\mathrm{R}$ square of $0.1 \%$.

Table 4: Rating of Management Graduates by Employers in Public/Private Sectors

\begin{tabular}{|l|l|c|c|c|c|}
\hline Parameter & \multicolumn{1}{|c|}{$\begin{array}{c}\text { Employers' } \\
\text { Organization type }\end{array}$} & $\mathbf{N}$ & Mean & Std. Dev. & Std. Error Mean \\
\hline $\begin{array}{l}\text { Rating of Management } \\
\text { Graduates }\end{array}$ & Public & 263 & 3.57 & .613 & .038 \\
\cline { 2 - 6 } & Private & 348 & 3.67 & .604 & .032 \\
\hline
\end{tabular}

Levene $\mathrm{F}=1.848 \mathrm{P}=.175 \mathrm{t}=-2.055 \mathrm{P}=.040$

Source: Authors' Fieldwork

A t-value of -2.055 and a $p$-vales of 0.04 revealed that a significant difference exist between the employers in private and public organizations in their rating of management graduates' performance. Evidence in Table 3 suggests that employers in private sectors with mean index of 3.67 were more satisfied with the performance of management graduates than those in the public sector whose mean evaluation stood at 3.57.

Table 5: Gender Influence on the Performance of Management Science Graduates from Nigerian Universities

\begin{tabular}{|l|l|c|c|c|c|}
\hline Parameter & Employee Sex & $\mathbf{N}$ & Mean & Std. Dev. & Std. Error Mean \\
\hline \multirow{2}{*}{$\begin{array}{l}\text { Performance of Management } \\
\text { Graduates }\end{array}$} & Male & 374 & 3.64 & .613 & .032 \\
\cline { 2 - 6 } & Female & 243 & 3.61 & .603 & .039 \\
\hline
\end{tabular}

$\mathrm{F}=.066 \mathrm{p}=.797 \mathrm{t}=.597 \mathrm{p}=.550$

Source: Authors' Fieldwork 
The figures arrayed in Table 4 reveal employers' equal perception of both the male and female management graduate employees by their employers. Refer to the t-value of 0.597 and $p$-value of 0.550 in Table 4 for confirmation.

Table 6: Employers' Rating of Management Graduates from Public/Private Universities

\begin{tabular}{|l|l|l|l|l|l|}
\hline Parameter & $\begin{array}{l}\text { Employees' } \\
\text { Organisation type }\end{array}$ & $\mathbf{N}$ & Mean & Std. Dev. & Std. Error Mean \\
\hline $\begin{array}{l}\text { Rating of Management } \\
\text { Graduates }\end{array}$ & Public & 460 & 3.63 & .618 & .029 \\
\cline { 2 - 6 } & Private & 168 & 3.64 & .592 & .046 \\
\hline
\end{tabular}

$\mathrm{F}=.494 \mathrm{P}=.482 \mathrm{t}=-.226 \mathrm{P}=.822$

Source: Authors' Fieldwork

The t-value of 0.226 and $p$-value of 0.822 are clear indications that management graduates from private universities are not significantly different from those in public universities in terms of their performance.

Table7: Comparative Analysis of Management Graduate Performance from the Different University Generations

\begin{tabular}{|l|l|c|l|l|}
\hline University Generation & N & Mean Rating & F & Sig. \\
\hline Third Generation & 192 & 3.59 & .765 & .466 \\
\hline First Generation & 250 & 3.63 & & \\
\hline Second Generation & 177 & 3.67 & & \\
\hline
\end{tabular}

Source: Authors' Fieldwork

The F-value of 0.765 and $p$-value of 0.466 shows that there is no significant difference in the rating of the various generational management graduates from Nigerian universities. In other words, employers rated management graduates from First, Second and Third Generational Universities as same. Judging from the mean rating of the various generational universities, it can be observed that the Second Generation Universities were rated best with mean 3.67 followed by First Generation Universities (3.63) and Third Generational Universities in the second and third positions respectively.

Table 8: Attributes of Management Science Graduates from Nigerian University

\begin{tabular}{|l|l|c|c|}
\hline $\mathbf{S} / \mathbf{N}$ & $\begin{array}{l}\text { Management Science Graduates } \\
\text { Attributes }\end{array}$ & Observations & Ranking \\
\hline 1 & Reliable & 491 & 1 \\
\hline 2 & Employable & 462 & 2 \\
\hline 3 & Hardworking & 448 & 3 \\
\hline 4 & Skilful innovative & 345 & 4 \\
\hline 5 & Honest & 333 & 5 \\
\hline 6 & Unskilful & 55 & 6 \\
\hline 7 & Unreliable & 52 & 7 \\
\hline 8 & Dishonest & 40 & 8 \\
\hline 9 & Lazy & 36 & 9 \\
\hline 10 & Unemployed & 21 & 10 \\
\hline
\end{tabular}

Source: Authors' Fieldwork 
Of the ten key attributes presented to the employers for rating the quality of management graduate from Nigerian universities, 491 selected reliable, followed by employable 462 , hardworking 448, skillful 345, honest 333 , unskillful 55, unreliable 52, dishonest 40, lazy 36 and lastly, unemployable 21. By implication, the employers feel that Nigerian graduates are reliable, employable and hardworking, as these were three most popular positive attributes used to qualify management graduate.

Table 9: Approaches to Improving Quality of Management Graduates from Nigerian Universities

\begin{tabular}{|c|c|c|c|}
\hline $\mathbf{S} / \mathbf{N}$ & $\begin{array}{l}\text { Suggested approaches to improving qualities of } \\
\text { graduates }\end{array}$ & Observation & Ranking \\
\hline 1 & Infrastructure & 87 & 1 \\
\hline 2 & Emphasis on practical training & 81 & 2 \\
\hline 3 & Improvement in research and development & 77 & 3 \\
\hline 4 & Management training and development & 74 & 4 \\
\hline 5 & Funding & 60 & 5 \\
\hline 6 & Conducive learning environment & 47 & 6 \\
\hline 7 & IT training & 24 & 7 \\
\hline 8 & Restructuring of curriculum & 15 & 8 \\
\hline 9 & Employment of qualified teachers & 13 & 9.5 \\
\hline 10 & Coworkers' commitment & 13 & 9.5 \\
\hline 11 & Developing hardworking and positive attitudes & 12 & 11 \\
\hline 12 & Proper record keeping/information management & 11 & 12 \\
\hline 13 & Effective government supervision/Quality control & 10 & 13 \\
\hline 14 & Elimination of corruption/Enhanced integrity & 9 & 14 \\
\hline 15 & Monitoring students' progress & 8 & 15 \\
\hline 16 & Less strike & 6 & 16 \\
\hline 17 & Effective leadership in university administration & 4 & 17 \\
\hline 18 & Inculcating educational values in students & 3 & 20.2 \\
\hline 19 & Responsiveness to students' needs & 3 & 20.2 \\
\hline 20 & Enhanced library & 3 & 20.2 \\
\hline 21 & Subsidized school fees/scholarship & 3 & 20.2 \\
\hline 22 & Improved reward system & 3 & 20.2 \\
\hline 23 & Collaboration with foreign counterparts & 2 & 23 \\
\hline 24 & Building good/solid foundation from basic education & 2 & 24 \\
\hline 25 & Enforcement of disciplines & 1 & 25 \\
\hline
\end{tabular}

Source: Authors' Fieldwork

The analysis of the employers' suggestions on how to improve graduates' quality identify the following five areas as critical: infrastructure, emphasis on practical training, improvement in research and development, management training and development and funding. 


\section{Discussions of Findings}

The employers' average assessment of management science graduates is not unexpected, given the general outcry of stakeholders about the poor level of infrastructure, incessant/protracted strikes, and poor ranking of Nigerian universities regionally and globally. Employers' evaluations in this study appears to be reminiscent of Odia's (2012) finding on the poor ( $7^{\text {th }}$ position) ranking of Nigeria's education among six other countries.

A clear distinction was observed between the employers in the public and private universities in their evaluation of Nigerian management graduates. The more positive rating by employers in the private may be ascribed to their commitment to new employees' orientation training.

The lower rating of Nigerian management graduates by employers in the public sector may not be unconnected to the observation of Dabalen, Oni, and Adekola (2000) on the decline in the share of graduates going into the public universities because of the falling standard. This result however supports that of Gunawardena (1997).

The findings of this study partially agree with the results obtained in the study carried out by Dabalen et al. (2000) that Nigerian Universities graduates employees are particularly deficient in technical skills and oral and written communication. In the present study, statistics showed that Nigerian management graduates were highly and positively perceived as good in oral and writing skills. Nevertheless, this result fully supports the finding of Adeyemo et al. (2010) in which graduates were rated first in oral and writing skills. While problem solving, /ICT were rated poorly in the $7^{\text {th }}$ and $8^{\text {th }}$ positions out of ten $(10)$ factors.

In the present study, the Nigerian management graduates were rated poorest in the area of computer/ICT skills. The poor performance of Nigerian management graduates in computer skills is line with Ibrahim and Dandago's (2013) study in which the business education graduates acknowledged that their inadequacy in modern technical skills limited their employability in the Nigerian labour market. The major reason for poor computer literacy may be linked to ill equipped computer laboratories in many universities. This is closely linked to the poor funding noted by Chiedu (2013) and others.

On a positive note, our result show cased that the Nigerian management graduates were better perceived on interpersonal skill than problems solving skills. The findings in this regard supports Imeokparia and Ediagbonya's (2012) study on the employability of Business education graduates in Nigeria in which they found that the thinking skills of Business Education graduates were not as good as their personal quality skills. One plausible conclusion is that too much emphasis is still been placed on theoretical approach rather than the problem solving and practical skills that would equip graduates with on-the-job skills.

The comparative result on the quality of graduates from public and private universities does not support the findings of Anho (2011) and Singh and Singh (2008). On the influence of age, this study tends to support Singh and Singh's (2008) work. The employers' equal rating of Nigerian Management Graduates from both the private and public universities is an indication that educational standard has generally deteriorated in Nigeria. The findings from this study show that variations exist in the opinions of employers the private and public organizations. This observation is related to the discoveries of Agbonna, Yusuf, Ajidagba and Olumorin (2009) on the employability of Nigerian graduates, in which they found that variations exist between the opinions of employers in the educational sector and those in the business sector.

Just as revealed in the study of Agbonna et al. (2009), our finding supports employers' opinion that the graduates were fairly employable, productive and trainable. On the observance of ethical standard, not much difference was noted between the present study and that of Adeyomo et al. (2010) who found that the surveyed graduates were negligent, careless and hostile at work. 


\section{Conclusions}

A review of the extant literature was conducted on the state of mandate delivery in Nigerian universities. In the process, the review unearth funding, inadequate modern facilities, incessant strikes, low entrepreneurial and technical skills, ICT training, brain drain, politicization of education, indiscipline, and insufficient and low quality lecturers as the major reasons for poor quality graduates.

Findings from the empirical analysis indicate that employers in the private sector are more of the opinion that Nigerian management science graduates are fairly employable. Secondly, no distinction was recorded between the male and female graduates in terms of their employability. In a similar manner, no image differential was noticed of the three generational graduates.

\section{Recommendations}

On the basis of the research findings, the following recommendations were made: Nigerian management students should be equipped with computer knowledge and skills needed for employment in the $21^{\text {st }}$ century labour market. To this end, NUC and other related agencies should develop a benchmark curriculum of management studies to include relevant skills and competencies such as ICT and problem solving skills. Emphasis should be placed on understanding ethical standard bothering on their profession. The students' leadership skill could be enhanced by various teaching method such as role play, team work/group work etc For the employers of labour, new graduates employees should be given proper orientation and training where they are trainable not minding the cost evolved in the training as this will in the long run increase the much needed productivity. There should be collaboration between employers of labour and the university curricula developers to close the gap between what is required in the industry and what the curriculum is offering students. On this note, greater (industry), the private sector involvement in curriculum consultation, faculty industrial attachment, student work-study placement within the institution and research funding would be helpful in enhancing graduate employability.

\section{References}

Abdullah Al-Mutairi, Kamal Naser and Muna Saeid. 2014. Factors Impact Business Graduates Employability: Evidence from Academicians and Employers in Kuwait, International Journal of Academic Research in Economics and Management Sciences July, 3(4). DOI: 10.6007/IJAREMS/v3-i4/1113 [Accessed 16 February 2017]

Abiola S. 2014. Nigeria's Educational System and its Unemployable Graduates. April 21,http://dailypost.ng/2014/04/21/abiola-solanke-nigerias-educational-system-unemployabl e-graduates/ [15.11.2016].

Adefuye, A 1999. Leadership and Human Resource Management, Personnel Management Journal. 10(21) pp 4-6.

Adeyemo, S. A., Ogunleye, A. O., Oke, C. O. and Adenle, S. O. 2010. A survey of factors determining the employability of science and technology graduates of polytechnics and universities in the Nigerian labour market. Journal of Science and Technology Education Research. 1(5), pp 99-106, October.

Agbonna, S. A., Yusuf, A., Ajidagba U. A. and Olumorin C. O. 2009. Assessing the Employability of Nigerian Graduates Using Employer-Based Assessments. A paper presented at the $1^{\text {st }}$ International Conference of the Collaboration of Education Faculties in Nigeria (CEFAN), held at the University of llorin, Kwara State, Nigeria from $12^{\text {th }}$ to $16^{\text {th }}$ July. 
Akanmu O 2011. Graduate Employment and Employability Challenges in Nigeria. Paper presented at The British Council Global Higher Education Conference, Hong-Kong, March.

Akhuemokhan, I. A., Raimu, L., and Sodoluwe, A. O. 2013. Entrepreneurship Education and Employment Stimulation in Nigeria. Journal of Studies in Social Sciences, 3(1), pp 55-79.

Akinyemi S., Ofem, I. B., and Ikuenomore S. O. 2012. Graduate Turnout and Graduate Employment in Nigeria. International Journal of Humanities and Social Science, 2(14) [Special Issue - July 2012].

Akpa, O. 2006. Sensitization seminar paper presented at the Centre for Entrepreneurial Development, Auchi Polytechnic, Auchi. (CEDAP) on Thursday, 21 December.

Alumode, B.E. 2006. Strategies for improving Human Resources Management for Quality Education in Universities in South Eastern States of Nigeria. Nigerian Journal of Educational Administration and Planning 6(1), pp 53-55

Ambepitiya, K. R. 2016. Employability of Graduates of Public and Private Management Education Institutes: A Case Study of Two Institutes in Sri Lanka. OUSL Journal, 11, pp. 113 -134 .

Andrews, J. and Higson, H. 2008. Graduate Employability, 'Soft Skills' Versus 'Hard' Business Knowledge: A European Study. Higher Education in Europe, 33(4), pp 411-422.

Anho, J. 2011. An Evaluation of the Quality and Employability of Graduates of Nigeria Universities. African Journal of Social Sciences, 1(1), pp 179-185.

Ariyawansa R. G. and Perera M. A. N. R. M. 2005. Determinants of Graduates Employability, Paper presented at the 10th International Conference of Sri Lankan Studies, University of Kelaniya, Sri Lanka.

Ariyawansa, R.G 2008. Employability of Graduates of Sri Lankan Universities. Sri Lankan Journal of Human Resource Management, 2(1) pp 91-104.

Balaceanu, C.; Zaharia, V.; Tilea, D.; Predonu, M.; Apostol, D. and Dogaru, M. 2013. Questionnaire on Analyzing the Degree of Satisfaction Regarding the Professional Skills of the Graduates As Perceived From The Employers' Perspective'. International Journal of Academic Research in Economics and Management Sciences, 2(1), pp 261-278.

Blom, A. and Saeki, H. 2011. Employability and Skill Set of Newly Graduated Engineers in India', Policy Research Working Paper 5640, available at: The World Bank South Asia Region Education Team April 2011, http://dx.doi.org/10.1596/1813-9450-5640 [23.10.2016] Branine, M. 2008. Graduate Recruitment and Selection in the UK: A Study of the Recent Changes in Methods and Expectations. Career Development International, 13(6), pp. 497-513.

Chiedu, A. 2013. Restoring Quality to Nigeria's Education System. January 23, www.punchng.com [Accessed 12 January 2017].

Cole G. A. 1993. Personnel Management: Theory and Practice, 3rd edition, Loader Jackson Printers, Arlesey, Bedfordshire, UK.

Cooper, D.R., and Schindler, P.S. 2011. Business research methods (11th eds.). New York: McGraw-Hill/Irwin.

Dabalen, A., Oni, B. and Adekola, O. A. 2000. Labor Market Prospects of University Graduates in Nigeria. Available at http://siteresources.worldbank.org/NIGERIAEXTN/Resources/labor market univ.pdf

[Accessed 23 October 2016]

Emeh IE, Nwanguma EO, and Abaroh JJ 2012. Engaging Youth Unemployment in Nigeria with Youth Development and Empowerment Programmes: The Lagos State in Focus. Interdisciplinary Journal of Contemporary Research in Business, 4, pp 1125-1141.

Ezenwafor, J. I. 2006. Strategies for Motivating Lecturers in Tertiary Institutions in the South East Zone for Better Performance to Assure Quality in Higher Education. Nigerian Journal of Educational Administration and Planning, 6(1), pp 165-169. 
Fraenkel, J.R., Wallen, N.E. 2000. How to design and evaluate research in education $\left(4^{\text {th }}\right.$ ed.). New York: McGraw-Hill.

Girden, E.R. 2001. Evaluating Research Articles (2nd eds.). London: Sage Publications.

Gunawardena, C (1997). 'What Employers' Look in University Graduates', Economic Review, People's Bank, Colombo, 22(10) Jan pp 19-22.

Hettige S. T. 2000. Students' Counseling and Welfare Service in the University System of Sri Lanka in Talent Development and Utilization, University of Kelaniya, Colombo.

Hodges, D. and Burchell, N. 2003. Business Graduate Competencies: Employers' Views on Importance and Performance. Asia Pacific Journal of Cooperative Education, 4(2), pp 16-22. Ibrahim, A. and Dandago K. I. 2013. Assessment of Views of Business Education Graduates on the Effect of Technological Advancement on their Employability in Nigerian Labour Market. International Journal of Academic Research in Progressive Education and Development. July, 2(3), pp 192-202. DOI: 10.6007/UARPED/v2-i3/106. [15.11.16] Imeokparia, P. and Kennedy, E. 2012. Employability of Business Education Graduates. International Research Journals, 3(8), pp 645-651.

Imeokparia, P. O and Ediagbonya, 2012. Employability of Business Education Graduates Education Research. 3(8), from http:/www.interesiournals.org// [11.2.2018]

MdSaad, M.; Robani, A.; Jano, Z. and Ab. Majid, I. 2013. Employers' Perception on Engineering, Information and Communication Technology (ICT) Students' Employability Skills. Global Journal of Engineering, 15(1), pp 42-47.

Obanya P. A. I. 2002 'Revitalizing education in Africa', Lagos: Stirling Honden Publishers. In Idaka, I. 2013.

Odia, E. O. and Agbonifoh, B. A. 2014. Consumer Perception of Service Quality in Management Education in Selected Nigerian Universities. The Nigerian Academy of Management Journal, 8(1), pp 34-44

Odia, E.O. 2012. Public Perception of the Nigeria Brand. Unpublished PhD. Thesis, Department of Business Administration, University of Benin, Benin City.

Odunaike K. O., Ijaduola K. O. and Epetimehin F. M 2012. Assessment of the Quality of Business Education Programme in Selected Higher Institutions in Ogun State. American Journal of Social and Management Sciences http://www.scihub.org/AJSMS doi:10.5251/ajsms.2012.3.4.140.144 [Accessed 22 December 2016]

Ofulue, J. I. and Nwakwushue-Okonkwo J. I. 2008. Vocational and Technical Education: The Road-map to National Development. Journal of Business Studies and Technology Development (JBSTD) 4(2), July pp. 166-170.

Okocha, S. 2008, Oct 6. Insight into Level of Education Decay in the Country. Newswatch. Special Anniversary Edition. pp 21-24.

Pitan, O. S. 2015. An Assessment of Generic Skills Demand in Five Sectors of the Nigerian Labor Market. Public and Municipal Finance, 4(1), pp 28-36.

Pitan, O. S. 2016. Towards Enhancing University Graduate Employability in Nigeria, Journal of Sociology and Anthropology, 7(1), pp 1-11.

Pitan, O. S. and Adedeji, S. O. 2012. Skills mismatch Among University Graduates in Nigeria Labor Market. US-China Education Review, I, pp 90-98.

Rufai, A. U., Bakar A. B. and Rashid, A. B. 2015. Developing a Sustainable Practical Model of Graduate Employability for Higher Education. International Journal of Education and Literacy Studies, 3(1), pp 42-51.

Saunders, V. and Zuzel, K. 2010. Evaluating Employability Skills: Employer and Student Perceptions. Bioscience Education, 15-2, 1 (June), available at: http://www.bioscience.heacademy.ac.uk/journal/vol15/beej-15- $2 . a s p x . ~\left[\begin{array}{llll}\text { Accessed } 23 \\ \hline\end{array}\right.$ October 2016]

Singh, G. and Singh, Sh. 2008. Malaysian Graduates' Employability Skills. UNITAR EJournal, 4(1), pp 15-45. 
Starmass International 2007. Your key to Business Success in China, available from: http://www.starmass.com/en/research_sampling_method.htm. [Accessed 23 October 2016] Struwig, F.W., Stead, G.B. 2001. Planning, Designing and Reporting Research. Cape Town: Pearson Education South Africa.

Ting, Sh. and Ying, Ch. 2012. Is There a Gap Between Practitioners' and Academicians' Perceptions on Business Graduates' Competencies in Malaysia. Journal of Education and Vocational Research, 3(5), pp 167-172.

\section{Bio-note}

Dr. Odia, E. O. is a Senior Lecturer in the Department of Business Administration at the University of Benin, Benin City, Nigeria. Her research area includes branding, green marketing, consumer behaviour, and gender issues. Before joining University of Benin in 2011, she acted as the HOD, Department of Accounting/Business Administration, Benson Idahosa University. She is an Associate Examiner for the National Open University of Nigeria (NOU) as well as an Assessor for Institute of Chartered Accountant of Nigeria (ICAN). She is a Member of The Academy of Management Nigeria and Organisation of Women in Science for Developing Countries (OWSD).

Imasuen Benedicta Okaima is a PhD student in the Department of Educational Studies and Management, Faculty of Education, University of Benin. She is currently doing a research on a thesis titled: Teacher Mobility and Students' performance. 